\title{
Relationship between the Belief System and Emotional Well-Being of Single Mothers
}

\author{
Faizah bte Abd Ghani ${ }^{1}$, Farah Adibah Ibrahim ${ }^{1}$, Azian Abd Aziz ${ }^{2}$ \& Mastura Mahfar ${ }^{3}$ \\ ${ }^{1}$ Faculty of Education, Universiti Teknologi Malaysia, Malaysia \\ ${ }^{2}$ Language Academy, Universiti Teknologi Malaysia, Malaysia \\ ${ }^{3}$ Faculty of Management, Universiti Teknologi Malaysia, Malaysia \\ Correspondence: Faizah bte Abd Ghani, Faculty of Education, Universiti Teknologi Malaysia, Malaysia. E-mail: \\ faizah-ag@utm.my
}

Received: October 8, 2015 Accepted: October 16, 2015 Online Published: November 20, 2015

doi:10.5539/ass.v11n27p28 URL: http://dx.doi.org/10.5539/ass.v11n27p28

\begin{abstract}
This study aimed to identify the relationship between the belief system and emotional well-being of single mothers in Kluang, Johor. This study involved 58 respondents using the purposive sampling technique. Questionnaires were used to identify the emotional well-being and respondents' belief system. Data were analysed using Statistical Package for the Social Science (SPSS 19.0). Descriptive statistics in the form of percentage, mean, and inferential statistics, namely, 'Pearson $r$ ' correlation analysis was used to identify the relationship between single mothers' emotions and their belief system. Results of the study found the single mothers' emotional well-being to be moderate $(\mathrm{M}=23: 56, \mathrm{~S} . \mathrm{D}=6.62)$ and their belief system to be high $(\mathrm{M}=$ 37.55 , S.D $=8.22$ ). In addition, the study also showed a significant difference between the single mothers' age, reason for becoming single mothers, occupation, number of dependent children and family members, in relation to the single mothers' belief system and emotional well-being. However, there was no significant difference in the relationship between their level of education and belief system. The study also showed a moderate correlation between the two variables $(r=0.665, p=0.000)$. Implications of the study are discussed and further research can be carried out on samples who have recently experienced a separation or divorce, to assess the short term and long term impact.
\end{abstract}

Keywords: emotional well-being, belief system, single mothers

\section{Introduction}

A single mother's emotional well-being is essential when facing numerous current issues and challenges. Task-overload, work related stress, poor social life, and arguments with ex-spouses are examples of problems faced by lone parents or single mothers (Kelly \& Voydanoff, 1985; Richards, 1989; Richards \& Schmiege, 1993). In addition, single or lone parents have multiple roles, and so face different pressures compared to other types of households, such as limited human resources, less emotional support, less assistance with household tasks and child care, less time available for social activities, and reduced participation in community life (Smith, 1980). As Kendig and Bianchi (2008) assert, single mothers experience a time deficit as a consequence of competing demands that limit the time they have available to care for their respective children.

In relation to statistical data of single mothers, Le and Miller (2013) reported that as of June 2005 the number of lone parent families with young children had increased to 463,000 in Australia, comprising 21 per cent of all families with young children (ABS, 2011). Meanwhile, the number of single mothers also increased to 32 per cent in the United States (Annie E. Casey Foundation, 2009). The number of single mothers is also increasing in the middle east, particularly in Iran, mainly due to the demise of a spouse (Khosravan, Salehi, Ahmadi, \& Mansoorian, 2013). In fact, more than 80 per cent of Iranian female-headed households are run by single mothers whose husbands have died (Khosravan, Salehi, Ahmadi, \& Mansoorian, 2013).

Becoming a single mother is stressful as these mothers have a high responsibility towards their children, with the stress experienced affecting their psychosocial and physical health, quality of life and economic standing (Hanson, Kaakinen, \& Gedaly-Duff, 2005; Wilcox, Evenson, \& Aragaki, 2003). Without a partner, it is difficult for single mothers to provide the time and attention that children receive in two-parent homes (Kendig \& Bianchi, 
2008). Single mothers also cite difficulties with child-rearing and report childcare as a major stressor of daily living (Wijnberg \& Reding, 1999). In addition, about 44 per cent of single mothers smoked daily as a result of facing more stress due to economic situation, occupation and family issues, compared to mothers with spouses (Sperlich, Maina, \& Noeres, 2013). As the number of single-mother increases, it is vital to better understand the parenting process unique to single mothers (Murry, Bynum, Brody, Willert, \& Stephens, 2001).

Single mothers who are able to cope with their problems will have a high emotional well-being. A theoretical approach that is often associated with the emotional consequences of individuals is the Rational Emotive Behavioural Therapy (REBT), introduced by Albert Ellis in the mid 1950s. The ABC Model introduced in the REBT approach greatly helps an individual in understanding the causes of emotional disturbances (Ellis, 2002; Dryden, 1995). Ellis (2002) asserted that positive consequences of emotion and behaviours are often associated with beliefs. If a person's assessment on a negative event is rigid, absolutistic and dysfunctional, the emotional and behavioural consequences are likely to be defeating and destructive (Ellis, 2002; Dryden \& Neenan, 2004). Alternatively, if a person's evaluative assessment about the event is preferential, flexible and constructive, the emotional and behavioural consequence (C) is likely to be self-helping and constructive (Ellis, 2002).

\subsection{ABC Model}

The ABC model, which is the main component in the REBT approach has been explained in great detail, particularly how emotional disturbance or stress experienced by individuals is due to their irrational belief system, rather than the negative events they experienced (Ellis, 1962; Ellis \& Bernard, 1983; Ellis \& Dryden, 1999). There are three main components in the ABC Model comprising activating events (A), belief system (B) and emotional and behavioral consequences $(\mathrm{C})$.

Activating event (A) - (A) could be defined as activating events that occur in people's life (Walen et al., 1992). People believe it as the cause of their problems (David et al., 2005).

Beliefs (B) - Beliefs (B) represent an individual's view about events (Dryden, 1999). Ellis (2004) proposed that beliefs (B) mediate the impact of activating events (A) on emotions and behaviour (C). Beliefs can be held about oneself, others and/or life events. The REBT theory advocates that beliefs can either be rational and healthy or irrational and unhealthy (David et al., 2005; Dryden, 1999). Rational beliefs represent any thoughts which are flexible, logical, realistic, and will aid goal attainment. Contrary to rational beliefs, irrational beliefs represent any thoughts that are unrealistic, rigid, extreme, illogical, absolutistic demands toward self, others, or life and prevent peoples from attaining their goals. Irrational beliefs are one of the main long-term sources and factors that maintain the distress and, as a consequence, may lead to many anxiety and mood disorders (David, Szentagotai, Lupu, \& Cosman, 2008).

Irrational beliefs will act as a mediator for the relationship between an event that will happen and reaction towards emotional disturbance and behaviour (Ellis, 1993). To explain in detail the irrational beliefs of an individual, Ellis (1962) initially classified 11 irrational beliefs causing emotional disturbances. However, subsequent studies have identified four categories of irrational beliefs, namely, 'demandingness', 'awfulizing', 'low frustration tolerance', and 'global evaluation' (Ellis \& Dryden, 1997; Dryden \& Ellis, 2003; DiGiuseppe et al., 2012). 'Demandingness' is viewed as a core belief in which a person ultimately will emphasize a situation as "must" or "must not" (Dryden \& Neenan, 2004). For instances, "I must be a good single mother all the time", and "My children must respect me".

'Awfulizing' refers to an individual's belief that an event is so awful, that it becomes not acceptable (Ellis \& Dryden, 1997). Typically, the characteristics of 'awfulizing' are expressed through an example such as, "It would be awful if I cannot get what I want". A single mother who has 'low frustration tolerance' will not be able to endure the negative events or experience any happiness if what he/she wants does not materialise (Dryden \& Neenan, 2004). The characteristics of this irrational belief could be expressed in a statement such as, "I can't stand it when I cannot be accepted by others". Meanwhile, 'global evaluation' appears when individuals overgeneralize about others, themselves, and the world when their demands are not met (Walen, DiGiuseppe \& Dryden, 1992). For example, this feeling could be manifested by saying "I am worthless if I cannot be a good single mother".

Consequences (C) - Consequences (C) represent undesirable emotional consequences (ueC) and undesirable behavioral consequences (ubC). C is a result of people's beliefs or perceptions. Rational beliefs (RBs) lead to functional consequences, whereas irrational beliefs (IBs) lead to dysfunctional consequences (David, et al., 2005). For example, C can be expressed through the phrase "I feel angry / anxious" while ubC can be manifested by becoming withdrawn, yelling, or throwing things. Figure 1 illustrates an overview of the main components of the ABC Model. 


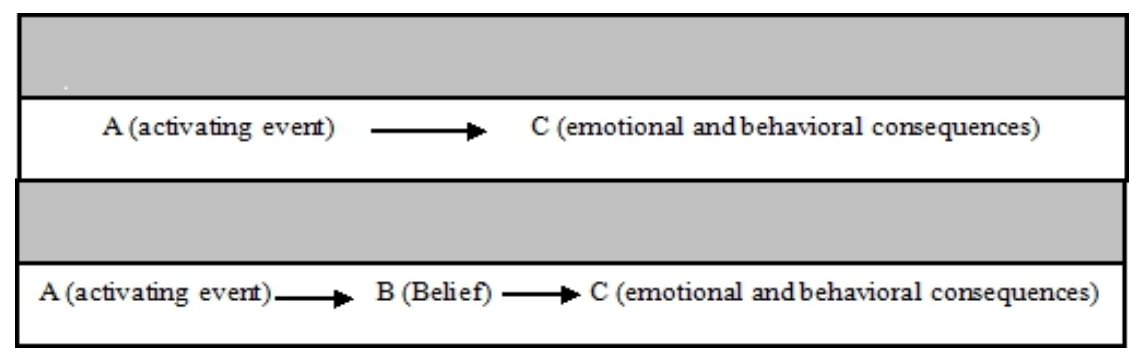

Figure 1. ABC Model (Adapted from Corey, 1986)

Most individuals assume that emotional disturbances and behaviors (C) originate from activating events (A) which may be external or internal (Ellis \& Dryden, 1997). However, the therapeutic process of REBT encourages the clients to understand that their dysfunctional emotional and behavioral responses (C) are largely due to their irrational beliefs (B), not the activating event (A).

Khosravan, Salehi, Ahmadi and Mansoorian (2013) stated that society regards single mothers or widows to be of lesser value, compared to women with husbands. In fact, the former group of women may even be perceived negatively. This in turn leads to a growth in negative or irrational thinking in single mothers, such as the feeling of repulsiveness and worthlessness, which is then manifested in the form of low self-confidence (Khosravan, Salehi, Ahmadi, \& Mansoorian, 2013). There is also a manifestation of other negative feelings among single mothers further worsened by lack of social sympathy. These negative thoughts and behaviours include 'loneliness and abandonment' and 'injustice and abuse', which entail a feeling of 'lack of trust' towards society. In addition, Joyce (2006) identified irrational parenting beliefs such as becoming too demanding displayed through absolutist and rigid beliefs that include 'should, ought, have to' statements. Irrational beliefs are also held by parents who cannot tolerate or bear an event or a set of circumstances that do not meet their expected standard for success (Joyce, 2006).

Starko (1991) examined the relationship between parents' irrational beliefs and stress for both mothers and fathers. The results indicated that a significant relationship exists between mothers' stress levels and irrational beliefs. This supports a previous research by Ackerman (1991) in which parents' irrational beliefs have been associated with negative emotional consequences. From the literature review, we can observe the importance of beliefs and how it is often associated with the emotional-well being of single mothers. However, there are no available local research that studies both beliefs and emotional well-being among single mothers in Malaysia. Therefore, this study was carried out to identify the relationship between the two variables.

Emotional well-being is important as it has a direct correlation with physical health, quality of life and personal achievements. Emotional well-being is the cornerstone to quality human capital, which is very much needed in the Malaysia context in attaining its aspirations to achieve a developed nation status by 2020. Significant changes in the socio cultural, socio-political, and socioeconomic environment in Malaysia today has transformed the pattern, life style and perspective of the community. These changes can be seen from the fundamental aspect of the family system itself. According to Azizi et al. (2009) and Rice (2001), families may be labelled into several types, namely, single-parent families, nuclear families, extended families, binuclear families which is formed when an initial family is split into two, communal families, and gay or lesbian families comprising adults of the same gender, and finally, cohabiting families. Thus, the definition for 'family' has become wider and not only synonymous with nuclear or basic family units (Azizi et al., 2009).

In Malaysia, the increasing divorce statistics has resulted in an increase of single mother families. In fact, data generated by the Population and Housing Census of Malaysia 2010, showed that 831,860 women, comprising 2.9 per cent of the total population of Malaysia, were either divorced or irrevocably separated. Thus it is highly likely that this group of the Malaysian community, is experiencing volatile changes in emotional well-being, which will have a major impact on families (Diyana et al., 2009), particularly in terms of emotional and mental well-being.

Thus, the emergence of the rapid growth of single parent families in Malaysia has resulted in an urgent need for assistance programmes focusing on them, as they need help in various aspects, particularly with regards to mental health. Challenges faced by single mothers as heads of their respective families and as the main breadwinners have placed immense pressure on the single mothers to accept and adapt to the current situation, particularly with respect to the expectations of society and economic demands (Diyana et al, 2009). This raises 
financial implications, especially for single mothers who do not work or those with very limited opportunities to get employment in view of their low educational background in addition to the issue of child care if they were out working (Faizah \& Hazirah, 2013). The matter is worsened by social stigma experienced by single mothers, creating further pressure.

Hence, the REBT approach holds that, individual's emotional and behavioural consequences originates from the individual's beliefs that include ideas or thought processes. In other words, the way people feel is largely influenced by how they think (Ellis \& Bernard, 2006). The irrational belief system of single mothers had been studied by Azmawaty Mohamad Nor et al. (2012). According to Azmawaty Mohamad Nor et al. (2012), generally, the perception of divorce among single mothers in most societies tends to be one-sided because it has been associated with negative consequences. Hence, divorce is often known as a negative concept and often labelled as "nasty divorces" (Azmawaty Mohamad Nor et al., 2005). In order to assist single mothers, their perception of divorce from a positive viewpoint has to be promoted.

Therefore, this article focuses on the emotional well-being and belief system of single mothers. Discussions are based on findings of a study, which investigated the correlation between single mothers' emotional well-being and belief system. Findings of this study could either be used as counselling guidelines or referral for future research.

\subsection{Definition}

\subsubsection{Emotional Well-Being}

Emotion is a feeling, an expression, or a cognitive reaction to a situation, which reflects the perspective or values held by an individual or society. Emotions may also act as an important element in communication and may generate solidarity in the community. Emotions in general can be labelled as anger, sadness, joy, shame, fear and so on, which play a significant role in decision-making. Mohd Azhar Abdul Hamid (2004) noted that changes in emotions could occur when a person is reacting to changes in their biological systems, such as facial expressions, voice, heart rate and hormones.

The Malay language Dictionary (1994), defines emotions as a strong feeling like sadness and anger, which affects the soul. Meanwhile, according to Hornby (1995), the Advanced Learners Oxford Dictionary, emotions are strong feelings involving feelings such as love, joy, hatred, fear, jealousy, feelings of pleasure or irritation. For instance, Spielberger (1999) defines the emotion of anger as "a psychological state or condition of a person with a subjective feeling of anger which vary according to severity, from mild dislike or annoyance to extreme hate and raging anger."

Well-being is a holistic concept in achieving physical and mental health, resulting in quality individuals within a community (Myers, Sweeney, \& Wittmer, 2005, p. 252). Emotional well-being is one of the dimensions that underlie the aspect of overall well-being as indicated by Anspaugh et al. (2010) and Hales (2005) as individuals' attitudes and beliefs about themselves and life. It encapsulates a positive and realistic self-concept, self-identity, belief system and awareness level of restraint.

Emotional well-being is the essence of mental health and has become a major issue and challenge in today's society. Nevertheless, emotional problems do not only affect an individual's mental well-being, but could also significantly affect an individual's physical health. Stress, depression and anxiety can contribute to endemic diseases such as digestive disorders, sleep disturbances, and lack of energy. Thus, the existence of physical problems on top of emotional problems would make treating the latter more challenging. This is in fact a global issue because a number of studies have identified depression to be one of the most dominant mental diseases among single mothers (Hatcher, 2008; Hilton \& Kopera-Fyre, 2006; Peden, Reyens, Hall, \& Grant, 2004).

Single mothers in Malaysia experience relatively similar emotional problems with their counterparts across the globe. Wan Halim Othman (1995) points out that single mothers, particularly those divorced or abandoned by their husbands often suffer from depression and mental stress. According to him, single mothers' negative perspective on marriage in addition to economic pressure, tend to cause these mothers to neglect their children or leave the children to be cared by the children's grandparents or close relatives. Such neglect is seen as an indicator of emotional instability and failure to manage stress well, resulting in single mothers fleeing rather than facing or 'fighting' the challenges they face. At that point in time, these single mothers perceived fleeing as the only way out for emotional and physical survival.

\subsubsection{Belief System}

The term 'belief system' is employed in various fields but has significant differences in meaning. Nevertheless, in general, the term may be used to describe life practices and beliefs that allow individuals to comprehend 
issues occurring around them or within themselves (só-Doménech Nescolarde-Selva dan Nescolarde-Selva, 2013). Key elements affecting the belief system may be classified into either internal or external, with one of the main elements being religious beliefs (Serap \& Ayse, 2013), which create resilience and control within an individual. Carter (1999) believes that resilience is closely associated with tradition and religious practices of a particular community, forming the values and principles of life that is expressed in the form of lifestyle.

Therefore, it is not surprising that an individual's belief system plays a significant role in every decision made in every aspect of life by the individual, particularly concerning family stability and responsibility (Wilcox, 2002). A positive belief system could increase the durability and resilience of single mothers in facing pressures in life, although single mothers with low income are more at risk due to economic factors (Brodsky, 2000). The belief system may also act as an effective coping system for single mothers, which is perceived to vary according to skills and willingness to face new challenges, taking advantage of available social networking or support system (Abd Hamid, Siti Rafiah, Salleh, \& Sakinah, 2013)

According to Peterson, Hamme, dan Speer (2002), belief in one self (self-control) has a significant influence in efforts to achieve either individual or community success. It is this belief that needs to be strongly inherent in single mothers for them to break the vicious cycle of problems faced, as asserted by Broussard (2010) who studied the mental and physical well-being of low-income single mothers. Self-belief is the expectation of an individual that something will occur through any means or method, which is considered valid, underpinned by scientific, religious or any other beliefs. Based on these perspectives, the expectation will then be converted into knowledge (Harvey, 1996).

The importance of self-belief which underpins inherent strength is of utmost importance as it influences any effort undertaken in enhancing the single mother's quality of life as a whole. This is because the expectations of mothers, particularly those of single mothers', vary according to age and personality especially after reaching midlife. Past studies have linked single mothers' personality traits with their social role, which plays an important role in shaping their self-esteem as single mothers (Newton \& Stewart, 2013). A study by Harvey, Frank, Gore and Batres (1998) which looked at the effects of self-esteem in relation to feelings of shame and guilt, found that these feelings of shame and guilt are the product of self-reflection caused by lack or violation of social norms or standards in a society. As Serap and Ayse (2013) assert, the main challenge for women in their effort to consolidate the family unit, is the lack of social recognition. Hence, single mothers' belief system should become an effective 'coping system' which is seen to change according to skills and readiness in facing new challenges, taking advantage of available social network or support system (Rafiah \& Siti Sakinah, 2013).

A study conducted by Carter (1999) showed that fortitude is strongly associated with religious traditions and practices of a community. For some single mothers, religious beliefs and conviction are central in sustaining their daily life and fostering inner strength. This suggests that religion and faith play an important role in not only shaping the perception of single mothers, but also acting as a coping mechanism. Additionally, faith may also have a significant effect on life decisions made by single mothers, influencing family stability and responsibility towards children (Wilcox, 2002), all of which are in fact synonymous with the multicultural society and religion in Malaysia. Brodsky (2000) concurs with this view as he too is of the opinion that religious belief and faith are a source of strength, which contributes towards the resilience of low-income single mothers facing economic pressures.

Apart from religious values, a study by Wan Ibrahim Wan Ahmad and Zainab Ismail (2010) who studied the profiles of single mothers abandoned by their husbands found that economic impact and the responsibility of raising children, greatly influence the single mothers' self-belief. The pressure and expectations of the community, together with the said responsibility continue to put single mothers under duress.

It is thus obvious that a positive belief system is of utmost importance in assisting single mothers to face life pressure whether economic or family related, or in facing social stigma. Individuals under stressful situations will tend to seek sympathy from other individuals capable of providing emotional support and reducing anxiety (Hewstone, 2008). Hence, social and welfare services provided by various government agencies and NGOs should be able to provide single mothers with the opportunity to empower themselves with the necessary life skills (Haleman, 2004) like strong will power, which stem from a positive and rational belief system.

\subsection{Objectives of Study}

In particular, this study aims to identify the relationship between single mothers' belief system and their emotional well-being. It also intends to look at the correlation between single mothers' belief system and emotional well-being in relation to their respective age, causes for becoming single mothers, occupation, as well as the number of dependent children and family members. 


\section{Method}

This study applies the quantitative approach because it specifically involves numerical and computable data. This is also a correlational study as it attempts to determine the existence and degree of relationship between the belief system as the independent variable with the single mothers' emotional well-being which is the dependent variable.

The selection process of the respondents was based on the purposive sampling method as the aim is to seek “...groups and individuals where...the processes being studied are most likely to occur." (Denzin \& Lincoln, 1994, p. 202). This type of sampling has the potential of providing depth of understanding. Therefore, this study involved 58 single mothers registered with the Family Development Foundation in Kluang, Johor Darul Ta'zim.

In this study, the instrument used was the questionnaire because of its practicality and effectiveness (Bubbie, 2010). The questionnaire comprises three sections, namely, Part A which is related to demographic questions, Part B which focuses on the belief system, and Part C which is related to emotional well-being. The Cronbach's Alpha value for the belief-system and emotional well-being were 0.849 and 0.927 respectively. Validity of the questionnaire was also attained from three experts in the field, comprising of experts from Guidance and Counselling, Education Psychology, and the Evaluation and Measurement, which as a whole showed a value of 90.66 .

\section{Analysis of Data}

Data were analysed using the Statistical Package for the Social Science (SPSS) version 16.0, in order to obtain the mean, percentage and frequency values. Meanwhile, a correlation analysis was used (inference) to examine the relationship between the respondents' belief system and their emotional well-being.

\section{Findings and Discussion}

4.1 Profile of Respondents

Table 1. Profile of single mothers

\begin{tabular}{|c|c|c|c|}
\hline \multicolumn{2}{|l|}{ Profile } & Frequency & Percentage \\
\hline \multicolumn{4}{|l|}{ Age: } \\
\hline \multicolumn{2}{|l|}{21 - 30 years old } & 1 & 1.7 \\
\hline \multicolumn{2}{|l|}{31 - 40 years old } & 2 & 3.4 \\
\hline \multicolumn{2}{|l|}{$41-50$ years old } & 11 & 19.0 \\
\hline \multicolumn{2}{|l|}{51 years old and above } & 44 & 75.9 \\
\hline \multicolumn{4}{|c|}{ Reason for becoming a single mother: } \\
\hline \multicolumn{2}{|l|}{ Divorce } & 14 & 24.1 \\
\hline \multicolumn{2}{|l|}{ Death of Husband } & 42 & 72.4 \\
\hline \multicolumn{2}{|l|}{ Abandoned by Husband } & 1 & 1.7 \\
\hline \multicolumn{2}{|l|}{ Other Reasons } & 1 & 1.7 \\
\hline \multicolumn{4}{|l|}{ Education Level: } \\
\hline \multicolumn{2}{|l|}{ No Education } & 5 & 8.6 \\
\hline \multicolumn{2}{|l|}{ UPSR (Primary Integrated Test) } & 13 & 22.4 \\
\hline \multicolumn{2}{|c|}{$\begin{array}{lll}\mathrm{PMR} / \mathrm{SRP} / \mathrm{LCE} & \text { (Lower } & \text { Secondary } \\
\text { Assessment) } & & \end{array}$} & 11 & 19.0 \\
\hline \multicolumn{2}{|l|}{ SPM/MCE (0 Level) } & 23 & 39.7 \\
\hline \multicolumn{2}{|l|}{ STPM/HSC (A Level) } & 1 & 1.7 \\
\hline \multicolumn{2}{|l|}{ Diploma } & 2 & 3.4 \\
\hline \multicolumn{2}{|l|}{ Others } & 3 & 5.2 \\
\hline \multicolumn{4}{|l|}{ Employment: } \\
\hline \multicolumn{2}{|l|}{ Government Servant } & 2 & 3.4 \\
\hline \multicolumn{2}{|l|}{ Private Employee } & 6 & 10.3 \\
\hline \multicolumn{2}{|l|}{ Work from Home } & 6 & 10.3 \\
\hline \multicolumn{2}{|l|}{ Pensioner } & 15 & 25.9 \\
\hline
\end{tabular}




\begin{tabular}{lcc}
\hline No employment/Stay at home mom & 24 & 41.4 \\
Others & 5 & 8.6 \\
Dependent Child: & 1 & 1.7 \\
Children not of school age & 19 & 32.8 \\
School going children & 14 & 24.1 \\
Children studying at the tertiary level & 7 & 12.1 \\
Unemployed Children & 16 & 27.6 \\
Others & & \\
Number of Dependents: & 42 & 72.4 \\
1 - 3 persons & 15 & 25.9 \\
$4-6$ persons & 1 & 1.7 \\
$7-9$ persons & & \\
\hline
\end{tabular}

From Table 1, in terms of the age profile, the data showed that $94.1 \%$ of the respondents were above 40 years of age, with the remaining $5.1 \%$ were below 40 years of age. The data is different from Mohd Ismail et al.'s (2006) where $70 \%$ of their single mother respondents were in the category of between 25 and 40 years old, while the remaining $40 \%$ were 41 years old and above. In terms of the reason for becoming single mothers, the data showed that the highest reason was due to the death of a husband $(72.4 \%)$, followed by divorce (24.1), abandoned by husband $(1.7 \%)$ and other reasons $(1.7 \%)$. These findings are similar to the findings of Syarifah (2003) who found that majority of women become single mothers due to the death of their respective spouses.

In terms of education level, the findings showed that majority (39.7\%) of the respondents have SPM qualifications which is equivalent to O level education. This was followed by UPSR or primary school level which comprised $22.4 \%$ of the respondents. Meanwhile, $19 \%$ of the respondents have PMR or lower secondary level education while $3.4 \%$ and $1.7 \%$ have diploma and STPM (A Level) qualifications respectively. The finding also showed that $8.6 \%$ of the respondents do not have any form of education while the remaining $5.2 \%$ have other types of qualifications. In terms of employment, majority of the respondents were unemployed which comprised $41.4 \%$, while the remaining $25.9 \%$ were pensioners living on a stipend. Single mothers who work from home and private sector comprised $10.3 \%$ respectively, while $3.4 \%$ worked in the government sector and $8.6 \%$ do odd jobs.

From the aspect of dependents, the findings indicated that majority of single mothers (32.8\%) have to support school going children, $27.6 \%$ have to support unhealthy children, $24.1 \%$ have to support children studying at the tertiary level, $12.1 \%$ have to support unemployed children and $1.7 \%$ have to support children not of school going age. The data showed that single mothers have to bear a huge responsibility to support their children despite the majority of them falling in the lower socio economic status. This brings us to the number of dependents that single mothers have to support. The data showed that majority of the single mothers $(72.4 \%)$ have to support at least 1 to 3 persons in the family, $25.9 \%$ have to support 5 to 7 persons, while $1.7 \%$ of single mothers have to support 7 to 9 persons.

\subsection{Emotional Well-Being}

Table 2 shows single mothers' belief system for each item. Although the overall findings of this study found that the emotional level of single mothers was average, with a mean value of 23.56 and standard deviation 6.62 , there were a few items of concern. For instance, item 2 with the statement 'I feel lonely when my husband passed away/abandoned me', despite showing an average mean level, had 46.5 per cent of the participating single mothers agreeing with the statement. This suggests the desire of single mothers to share their problems as individuals who are stressed tend to look for sympathy from other individuals who can afford them emotional support and give them peace of mind as (Hewstone, 2008). Likewise for Item 3 with the statement 'I cannot contain my sadness when my children asked about their father' with 41.4 per cent of the single mothers agreeing. 
Table 2. Emotional well-being items of single mothers

\begin{tabular}{lcccc}
\hline \multicolumn{1}{c}{ Item } & Agree (\%) & Disagree (\%) & Mean & Level \\
\hline $\begin{array}{l}\text { 1. I quickly become irritated when asked about personal } \\
\text { problems. }\end{array}$ & 22.4 & 77.6 & 1.9 & Low \\
$\begin{array}{l}\text { 2. I feel lonely when my husband passed } \\
\text { away/abandoned me. }\end{array}$ & 46.5 & 53.5 & 2.7 & Average \\
$\begin{array}{l}\text { 3. I cannot contain my sadness when my children asked } \\
\text { about their father. }\end{array}$ & 41.4 & 58.6 & 2.8 & Average \\
$\begin{array}{l}\text { 4. I feel calm despite having to face numerous } \\
\text { challenges. }\end{array}$ & 65.5 & 34.5 & 3.4 & Average \\
$\begin{array}{l}\text { 5. I'm bored with my current life. } \\
\text { 6. I'm not easily stressed despite being burdened by } \\
\text { difficult challenges. }\end{array}$ & 27.5 & 72.5 & 2.1 & Low \\
$\begin{array}{l}\text { 7. I often brood when thinking of challenges faced. } \\
\text { 8. I do not believe that every problem can be solved well } \\
\text { without my husband by my side. }\end{array}$ & 25.8 & 36.2 & 3.4 & Average \\
$\begin{array}{l}\text { 9. I feel very disappointed if I do not attain what I want } \\
\text { in life. }\end{array}$ & 24.2 & 74.2 & 2.3 & Low \\
$\begin{array}{l}\text { 10. I easily blame myself for any untoward incidents } \\
\text { occurring in life. }\end{array}$ & 22.4 & 79.4 & 2.3 & Low \\
\hline
\end{tabular}

\subsection{Belief System}

Table 3. Self belief items of single mothers

\begin{tabular}{|c|c|c|c|c|}
\hline Item & Agree (\%) & Disagree (\%) & Mean & Level \\
\hline 1. I must always excel in life. & 88.1 & 11.9 & 4.1 & High \\
\hline $\begin{array}{l}\text { 2. I would like to ensure that I do not fail in achieving } \\
\text { any goals in life. }\end{array}$ & 80.8 & 19.2 & 3.8 & High \\
\hline $\begin{array}{l}\text { 3. I accept what is happening in my life without the } \\
\text { presence of my husband. }\end{array}$ & 81.7 & 18.3 & 3.8 & High \\
\hline $\begin{array}{l}\text { 4. I should refrain from resolving any problems that I am } \\
\text { facing. }\end{array}$ & 23.4 & 76.6 & 2.7 & Average \\
\hline $\begin{array}{l}\text { 5. I view problems that occur as a challenge rather than a } \\
\text { burden. }\end{array}$ & 91.3 & 8.7 & 4.0 & High \\
\hline $\begin{array}{l}\text { 6. I should not have loss a person whom I love in my } \\
\text { life. }\end{array}$ & 47 & 53 & 3.0 & Average \\
\hline $\begin{array}{l}\text { 7. The hardship I am going through in life is God's } \\
\text { punishment to me. }\end{array}$ & 63.8 & 36.2 & 3.4 & Average \\
\hline $\begin{array}{l}\text { 8. When committing a mistake, I always tell myself "I'm } \\
\text { not a perfect human being". }\end{array}$ & 68.7 & 31.3 & 3.5 & Average \\
\hline 9. My life need not necessarily be bad all the time. & 76.6 & 23.4 & 3.6 & Average \\
\hline $\begin{array}{l}\text { 10. I think the world has become meaningless since the } \\
\text { absence of my husband. }\end{array}$ & 4.4 & 95.6 & 1.8 & Low \\
\hline $\begin{array}{l}\text { 11. I am not necessarily always right in presenting my } \\
\text { views. }\end{array}$ & 72.4 & 27.6 & 3.5 & Average \\
\hline $\begin{array}{l}\text { 12. The demise of (or being abandoned by) my husband } \\
\text { has certainly made my life difficult. }\end{array}$ & 33.3 & 66.7 & 2.2 & Low \\
\hline
\end{tabular}

Overall, the results showed that the respondents' belief system is at a high level with a mean value of 37.55 and standard deviation 8.22 Table 3 shows item 1 with the statement "I must always excel in life", item 2 "I would 
like to ensure that I do not fail in achieving any goals in life." item 3 "I accept what is happening in my life without the presence of my husband," 'and item 5, "I view problems that occur as a challenge rather than a burden" to have high mean values, suggesting that the single mothers surveyed were highly rational in nature. This assumption is further supported with the results of other items that showed the respondents' positive rationalization.

Nevertheless, the study found 33.3 per cent of the respondents to agree with the statement 'the demise of (or being abandoned by) my husband has certainly made my life difficult'. In addition, 47 per cent of the respondents agreed with the statement in item 6, namely, 'I should not have loss a person whom I love in my life', which suggests that these respondents lack a rational belief system as they are rejecting and questioning the will of God and their divine destiny. This finding implies that some respondents have an irrational belief system in trying to escape from dealing with the problems faced. This is consistent with a study conducted by Cairney et. al. (2003) which found single mothers formulating several strategies in dealing with challenges and pressures due to the absence of their respective spouses, which among others include avoidance strategy which involves not facing or solving the said problem.

Furthermore, this study also shows that 49 per cent of the respondents disagreed with the statement 'the hardship I am going through in life is God's punishment to me'. This finding contradicted the finding of another study, which found that trust or faith in religion is a source of strength for low-income mothers despite economic pressures.

4.4 Demographic Factors and Their Impact on the Belief System and Emotional Well-Being of Single Mothers

Table 4. ANOVA statistics showing the relation between demographic factors and belief system and emotional well-being of single mothers

\begin{tabular}{ccccccc}
\hline \multirow{2}{*}{ Demographic Factors } & \multicolumn{3}{c}{ Belief System } & \multicolumn{3}{c}{ Emotional Wellbeing } \\
\cline { 2 - 7 } & df & F & Sig & df & F & Sig \\
\hline Age & 19 & 2.101 & $.035^{*}$ & 20 & 2.582 & $.009^{*}$ \\
Reason for Becoming Single Mothers & 19 & 4.603 & $.000^{*}$ & 20 & 6.604 & $.000^{*}$ \\
Employment & 19 & 2.155 & $.030^{*}$ & 20 & 1.943 & $.047^{*}$ \\
Dependent Children & 16 & 3.108 & $.007^{*}$ & 17 & 2.386 & $.022^{*}$ \\
Total Dependents & 17 & 2.040 & $.047^{*}$ & 18 & 2.642 & $.010^{*}$ \\
Education Level & 19 & 1.046 & .447 & 20 & 3.174 & $.002^{*}$ \\
\hline
\end{tabular}

* significant level 0.05 level $\mathrm{p}<.05$

Table 4 shows the impact of demographic factors on the variables of belief system and emotional well-being of single mothers. Based on the data generated, a significant difference was shown arising from age factor, reasons for becoming single mothers, employment, dependent children and family members. These factors are synonymous with the ability to seek and obtain the necessary skills in enhancing the economic status of single mothers. Economic status in fact is the main indicator for problems faced by single mothers, particularly in Malaysia (Faizah, 2013). This finding is consistent with the disclosure of previous studies that show the effects of demographic factors involving poverty and high family dependents among single mothers to cause social polemic, with dire consequences to the psyche of single mothers and their respective children. This is of concern, as single mothers living in poverty are associated with the inability to provide their children with adequate sustenance and education (Roshanim, 2004). These single mothers are also prone to become involved in social ills and experience psychological problems (Faizah \& Azian, 2013).

With regards to the single mothers' education level, it was found that this variable only influenced the single mothers' emotional well-being, with no effect on their belief system. Nevertheless, it should be noted that education could have a positive impact on other aspects such as health, work environment, and family (Diyana Ishak et al., 2009). Better economic standing in line with higher education level will inevitably affect self-esteem, particularly confidence, mindset and action (Cheesemen et al., 2011). 
4.5 Relationship between Demographic Factors on the Belief System and Emotional Well-Being of Single Mothers

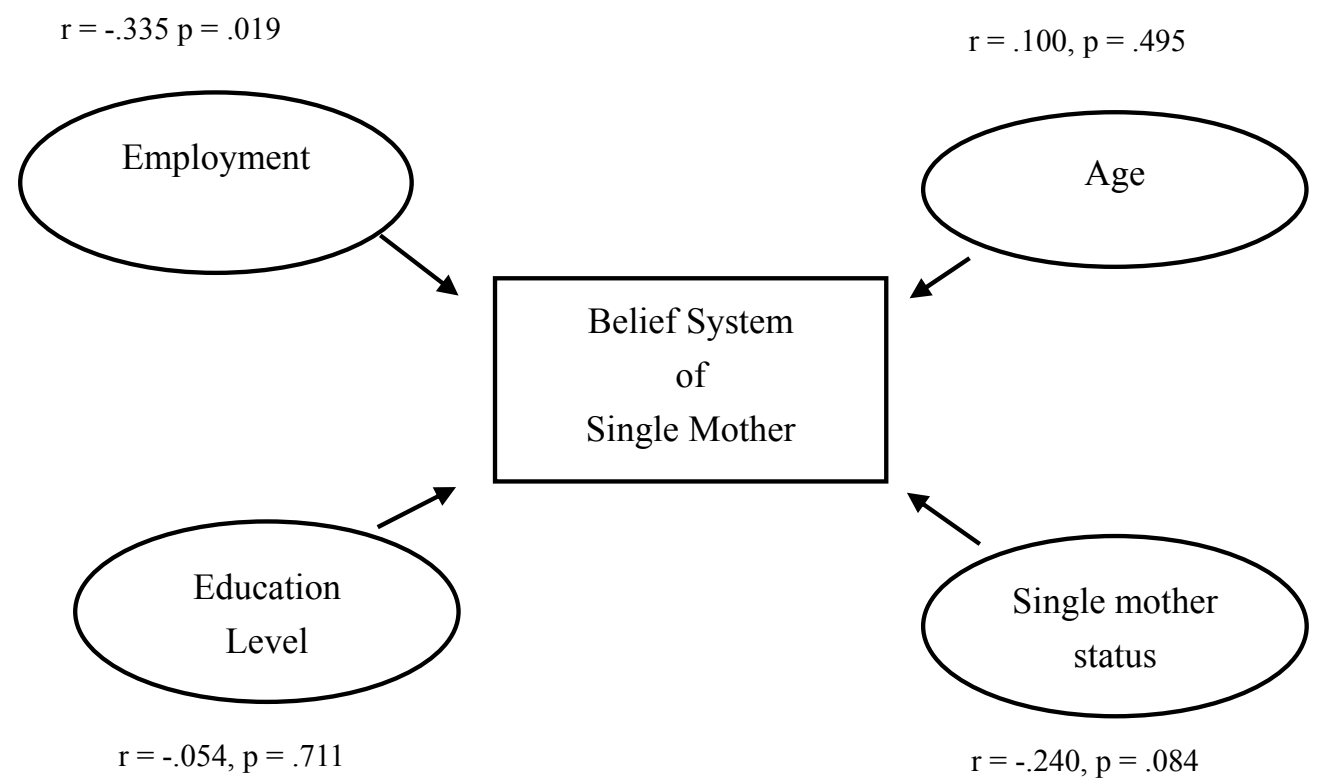

Figure 1. Correlation framework between demography and belief system

Based on Figure 1, correlation factors between the belief system of single mothers and demographic factors show that employment, single mother's status (reason for becoming a single mother), and education level have a negative relationship with correlation coefficient score of $-.335,-.240$, and -.054 respectively. Meanwhile only age shows a positive relationship with correlation coefficient score .100. This shows that employment, single mother status, and education level does not affect the belief system of single mother. Neither do age because although it has a positive relationship, it is weak and the value is not significant to show a strong relationship.
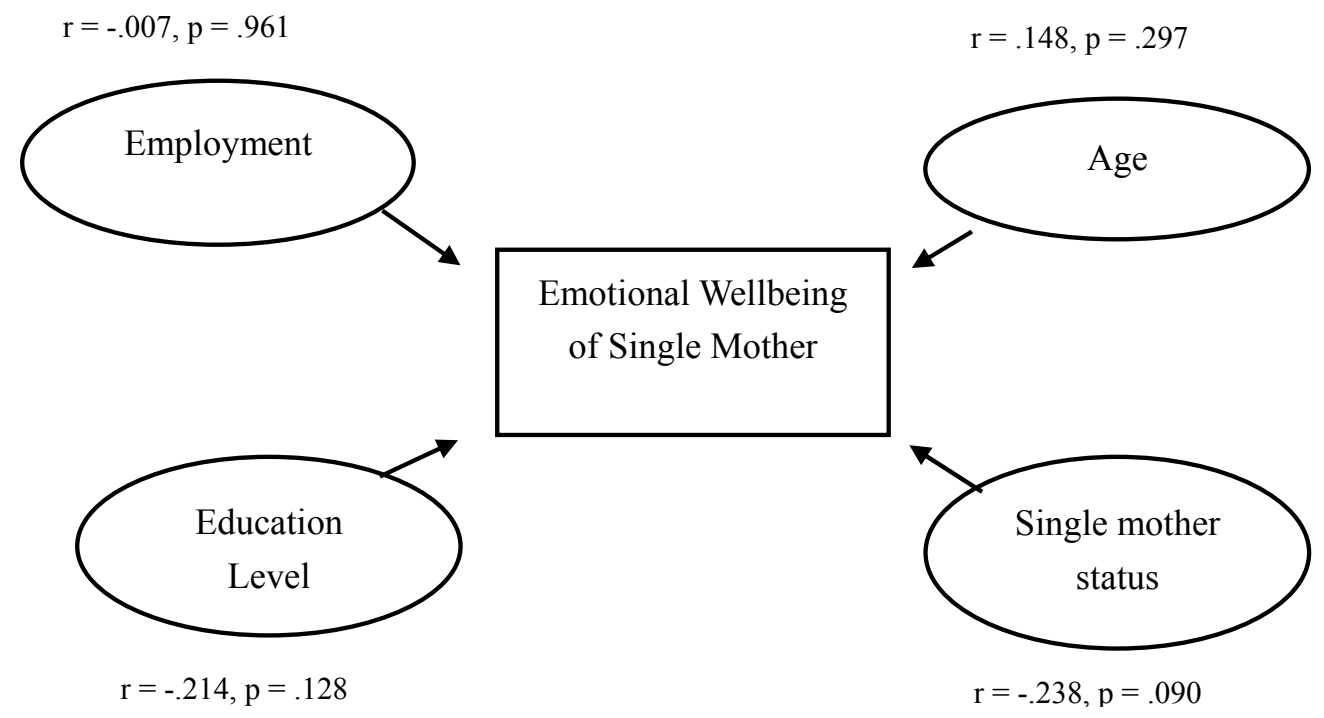

Figure 2. Correlation framework between demography and emotional wellbeing

On this figure, it follows the same trend as the previous variable. Only age shows a positive relationship with a correlation coefficient score of .148, while employment, single mother's status, and education level show a negative relationship with correlation coefficient score $-.007,-.238$, and -.214 respectively. This signifys that 
there is no relationship between employment, single mother status, education level and even age to emotional wellbeing of single mother.

From the analysis done on the demographic factors and the variables on both figure, it can be said that demographic background of single mothers does not give a significant relationship towards the bellief system of single mothers. This is true on account that many single mothers faced stress and emotional disturbance from the dual role playing in the family (Kendig \& Bianchi, 2008). The time deficit to take care of the children in addition to low emotional support from the community, contributed greatly to the well-being of single mothers (Smith, 1980). Therefore from the theory given, demographic factors is not an activating event to cause enough effect to the belief system and emotional well-being of single mothers. This result confirmed previous data that showed that most single mothers face issues and challenges with task overload (Kelly \& Voydanoff, 1985; Richards, 1989; Richards \& Schmiege, 1993), multiple roles, less assistance in household and child care, and also less time available for social activities (Smith, 1980).

\subsection{Relationship between Belief System and Emotional Well-Being}

Table 5. Correlation between belief system and emotional well being of single mothers

\begin{tabular}{ccc}
\hline & \multicolumn{2}{c}{ Emotional Wellbeing } \\
\cline { 2 - 3 } & $\mathrm{r}$ & Sig \\
\hline Belief System & $.665^{* *}$ & .000 \\
\hline ** Correlation is significant at the 0.01 level (2 tailed) $\mathrm{P}<0.01$ & &
\end{tabular}

Table 4 shows the correlation between the belief system and emotional well-being of single mothers. The relationship between emotional impact and the belief system was obtained through a correlation analysis. According to Rowntree (1981) and Azwani (2010), a particular relationship can be assessed through the $\mathrm{p}<0.05$ value. There is a strong relationship between emotions and the belief system, with an $r$ value of 0.665 and $p$ value of 0.000 (see Table 4) which is smaller than the set 0.05 significance level. This indicates that belief system has a relationship with the emotional well-being of single mothers in Kluang. The result was consistent with studies by Coleman \& Karraker (1997) and Jones \& Prinz (2005) in which higher parental efficacy or beliefs has been found to be related to lower depressive symptom scores and stress, and to higher enjoyment from the parenthood status. Among parents who experienced the same level of parental tension, those with a higher sense of parental efficacy reported better mental health (Kwok \& Wong, 2000). Based on the REBT approach, as negative emotion is largely due to irrational beliefs, any changes to the irrational belief will lead to the reduction of emotional disturbances and increase the emotional well-being, which is a major purpose of REBT (Ellis \& Bernard, 2006; Vernon, 2004).

According to the findings, the emotional well-being of single mothers surveyed in Kluang Johor is not at an alarming level. Nevertheless, this level may to some extent be due to factors of age and duration of becoming single mothers. The time duration may lead to the assumption that the respondents have become accustomed to the current situation or the trauma caused by the loss has been dulled over time. Additionally, support and assistance as well as sound economic resources have the ability to enhance the single mothers' emotional well-being. It was also found that a rational self belief system runs in tandem with a strong emotional well-being. The impact of the emotional well-being on the belief system is one of the key indicators in the efforts of the Malaysian government and other parties to enhance the productivity level of Malaysian citizens, making positive emotional well-being the thrust supporting national development.

\section{Limitation of the Study}

The findings of the study cannot be generalised to single mothers in Malaysia. It is likely that respondents of the study are already accustomed to their current situation, whereby the suffering, and emotional instability phase has ended. In addition, as the respondents were willing to participate in the study, there is a probability that single mothers who are really facing emotional problems and self-belief did not come forward as they tend to be defensive and untrusting. This gives rise to the question whether women who had recently become single mothers can control their emotions and still remain rational. However, the results showed that the level of emotional well-being among single mothers is moderate. This should be given due attention as the results of the study showed that there was a significant relationship between the single mothers' belief system and emotional well-being. Thus, further in-depth research should be carried out to identify what exactly could contribute to the 
positive emotional well-being of single mothers. Further investigations are also needed to provide a different perspective and to consolidate existing findings.

As a whole, this study has looked at the relationship between the belief system of single mothers and their emotional well-being. Findings of this study suggest that support and assistance rendered are capable of positively affecting single mothers in the long run. Emotional well-being and a positive belief system can add significant value to self-satisfaction and overall productivity. Citizens who are highly rational and emotionally healthy are valuable human capital assets not only to the nation, but also to the religion.

\section{Conclusion and Recommendations}

In general, these findings indicate that the belief system of single mothers is positive, while the level of their emotional well-being is moderate. The data obtained may act as important information that can be used by relevant stakeholders like the Family Development Foundation and other NGOs to gain insights into the plight faced by single mothers. This would enable them to plan and implement strategies that could assist in addressing the problems afflicting single mothers to fully realize Vision 2020 towards a truly modern and advanced Malaysia. Fostering a resilient spirit among Malaysians who are able to shoulder the aspirations of the country is of paramount importance. Thus, assistance and collaboration from all stakeholders should be mobilised in further strengthening the belief system of single mothers towards achieving prosperity and positive well-being. If single mothers' irrational belief system were to be left unaddressed, without receiving adequate assistance and support, other negative effects such as suicide and involvement in prostitution might become prevalent among this group of women. Thus, single mothers plagued with problems, especially those living in poverty and experiencing irrational belief system should be provided due assistance.

A specific approach implemented through programs involving the participation and cooperation of all stakeholders should be pursued in assisting single mothers. Cooperation of the State government and volunteers whether government officials or from NGOs especially those championing the plight of single mothers, in addition to the attitude of the single mothers themselves, need to be mobilised and integrated. This is to enable issues and challenges faced by single mothers to be addressed in a more strategic and structured manner, thereby contributing towards enhancing single mothers' physical and emotional well-being.

\section{References}

Abd Hamid, S. R., \& Salleh, S. (2013). Exploring single parenting process in Malaysia: issues and coping strategies. Procedia - Social and Behavioral Sciences, 84, 1554-1559. http://dx.doi.org/10.1016/j.sbspro. 2013.06.718

Ackerman, K. A. (1991). Irrational beliefs and parenting stress (Unpublished doctoral dissertation). University of Alberta, Canada.

Afifi, T. O., Cox, B. J., \& Enns, M. W. (2006). Mental health profiles among married, never-married, and separated/divorced mothers in a nationally representative sample. Social psychiatry and psychiatric epidemiology, 41(2), 122-129. http://dx.doi.org/10.1007/s00127-005-0005-3

Annie E. Casey Foundation. (2009). Kids count indicator brief. Increasing the percentage of children living in two-parent families. Retrieved from http://www.aecf.org/ /media/Pubs/Initiatives/KIDSCOUNT/K/ KIDSCOUNTIndicatorBriefIncreasingthePercentage/Two Parent Families.pdf

Anspaugh, D. J., Hamrick, M., \& Rosato, F. (2010). Wellness: Concepts and Applications. McGraw-Hill Humanities/Social Sciences.

Brodsky, A. (2000). The role of religion in the lives of resilient, urban, African American, single mothers. Journal of Community Psychology, 28, 199-219. http://dx.doi.org/10.1002/(SICI)1520-6629(200003)28: 2<199::AID-JCOP7>3.0.CO;2-3

Cairney, J., Boyle, M., Offord, D. R., \& Racine, Y. (2003). Stress, Social Support and Depression in Single and Married Mothers. Soc Psychiatry Psychiatric Epidemiol, 38, 442-449. http://dx.doi.org/10.1007/s00127003-0661-0

Carter, C. (1999). Church burning in African-American communities: Implications for empowerment practice. Social Work, 44, 62-68. http://dx.doi.org/10.1093/sw/44.1.62

Cheesemen, S., Ferguson, C., \& Cohen, L. (2011). The Experience of Single Mother: Community and Other External Influences Relating to Resillience. The Australian Community Psychologist, 23(2), 32-46.

Coleman, P. K., \& Karraker, K. H. (1997). Self-efficacy and parenting quality: Finding and future applications. 
Development Review, 18, 47-85. http://dx.doi.org/10.1006/drev.1997.0448

Corey, G. (1986). Theory and practice of counseling and psychotherapy. Pacific Grove, CA: Brooks / Cole.

David, D., Montgomery, G. H., Macavei, B., \& Bovbjerg, D. (2005). An empirical investigation of Albert Ellis' binary model of distress. Journal of Clinical Psychology, 61, 499-516. http://dx.doi.org/10.1002/jclp.20058

David, D., Szentagotai, A., Lupu, V., \& Cosman, D. (2008). Rational emotive behavior therapy, cognitive therapy, and medication in the treatment of major depressive disorder: A randomized clinical trial, posttreatment outcomes, and six-month follow-up. Journal of Clinical Psychology, 64, 728-746. http://dx.doi.org/10.1002/ jclp. 20487

Denzin, N. K., \& Lincoln. (1994). Handbook of Qualitative Research. Thousand Oaks: Sage.

DiGiuseppe, R., Doyle, K., Dryden, W., \& Backx, W. (2012). A practitioner's guide to Rational-Emotive Therapy (3rd ed.). Oxford: Oxford University Press.

Dryden, W. (1995). Rational emotive behaviour therapy: A reader. Bonhill Street, London: SAGE.

Dryden, W. (1999). Rational emotive behaviour therapy: A personal approach. Bicester, Oxon: Winslow Press Limited.

Dryden, W., \& Ellis. (2003). Albert Ellis! London: SAGE Publications Ltd.

Dryden, W., \& Neenan, M. (2004). The rational emotive behavioural approach to therapeutic change. London: SAGE.

Ellis, A. (1962). Reason and emotion in psychotherapy. Secaucus, NJ: Citadel

Ellis, A. (1993). Changing Rational-Emotive Therapy (RET) to Rational-Emotive Behavior Therapy (REBT). The Behavior Therapist, 16(10), 257-258.

Ellis, A. (2002). Overcoming resistance: A rational emotive behavior therapy integrative approach (2nd ed.). New York: Springer Publishing Company.

Ellis, A., \& Bernard, M. E. (1983). Rational-Emotive approaches to the problem of childhood. New York: Plenum Press.

Ellis, A., \& Bernard, M. E. (2006). Rational emotive behavioral approaches to childhood disorders: Theory, practice and research. New York: Springer Publishing Company. http://dx.doi.org/10.1007/b137389

Ellis, A., \& Dryden, W. (1997). The practice of Rational Emotive therapy (2nd ed.) New York: Springer.

Ghani, F. A., \& Hashim, H. b. (2013). Challenges and Locus Control Among Single Mothers in Muar, Johor. Journal of Emerging Trends in Educational Research and Policy Studies, 4(5), 760-765.

Haleman, D. L. (2004). Great Expectations: Single Mothers in Higher Education. International Journal of Qualitative Studies in Education, 17(6). http://dx.doi.org/10.1080/0951839042000256448

Hales, D. (2005). An Invitation to Health (11th ed.). Belmont, CA: Thomson \& Wadsworth.

Hamid, M. A. A. (2004). Panduan Meningkatkan Kecerdasan Emosi. PTS Publications and Distributors Sdn. Bhd.

Hanson, S., Kaakinen, J., \& Gedaly-Duff, V. (2005). Family Health Care Nursing: Theory, Practice, and Research (3rd ed.). Philadelphia: F.A. Davis Press.

Hatcher, J. (2008). Predictors of depression for low-income African American singlemothers. Journal of Health Disparities Research and Practice, 2, 89-110.

Hewstone, M. (2008). Introduction to Social Psychology; A European Perspective (4th ed.). Blackwell.

Hilton, J., \& Kopera-Frye, K. (2006). Loss and depression in cohabiting and noncohabiting custodial single parents. The Family Journal, 14, 28-40. http://dx.doi.org/10.1177/1066480705282053

Hornby, A. S. (1995). Oxford Advanced Learner's Dictionary of Current English. Oxford: University Press.

Isahak, D., Pamini, D., \& Idris, N. A. H. (2009). Isu dan Cabaran Ibu Tunggal Dalam Menghadapi Perubahan Persekitaran Global. Prosiding Kebangsaan Ekonomi Malaysia (PERKEM 1V), Kuantan, Pahang, 2-4 Jun 2009.

Jones, T. L., \& Prinz, R. J. (2005). Potential roles of parental self-efficacy in parent and child adjustment: A review. Clinical Psychology Review, 25, 341-363. http://dx.doi.org/10.1016/j.cpr.2004.12.004 
Joyce, M. R. (2006). A develomental, rational emotive behavioral approach for working with parents. In A. Ellis, \& M. E. Bernard (Eds.), Rational-emotive treatment of childhood problems (pp. 117-212). New York: Plenum Press.

Kavas, S., \& Hoşgör, A. G. (2013). The Parenting Practice of Single Mothers in Turkey: Challenges and Strategies. Women's Studies International Forum, 40, 56-67. http://dx.doi.org/10.1016/j.wsif.2013.05.004

Kelly, R. F., \& Voydanoff, P. (1985). Work/family role strain among employed parent. Family Relations, 34(3), 367-374. http://dx.doi.org/10.2307/583575

Kendig, S. M., \& Bianchi, S. M. (2008). Single, cohabitating, and married mothers' time with children. Journal of Marriage and Family, 70(5), 1228-1240. http://dx.doi.org/10.1111/j.1741-3737.2008.00562.x

Khosravan, S., Salehi, S., Ahmadi, F., \& Mansoorian, M. R. (2013). Social support: The most important need of young Iranian single-parent widows on their path to widowhood. International Journal of Nursing Practice, 19, 274-280. http://dx.doi.org/10.1111/ijn.12068

Kwok, S., \& Wong, D. (2000). Mental health of parents with young children in Hong Kong: The roles of parenting stress and parenting self-efficacy. Child Adolescenct Social Work Journal, 5, 57-65. http://dx.doi.org/10.1046/j.1365-2206.2000.00138.x

Le, A. T., \& Miller, P. W. (2013). Lone mothers' time allocations: choices and satisfactions. Australian Journal of Social Issues, $48,1$.

Mat Nor, A. b. (2010). Profil Personaliti dan Prestasi Kaunselor Sekolah Menengah Daerah Kota Tinggi. Universiti Teknologi Malaysia: Tesis Sarjana.

Mohamad Nor, A., Jaladin, R. A. M., Karim, D. N. F. M., \& Ahmad, N. (2012). From Nasty To Healthy Divorce: A Marriage And Family Therapy Model For Working Effectively With Divorcing Malay-Muslim Couples. Malaysian Online Journal of Counseling, 3.

Murry, V., Bynum, M. S., Brody, G. H., Willert, A., \& Stephens, D. (2001). African American single mothers and children in context: A review of studies on risk and resilience. Clinical Child and Family Psychology Review, 4(2), 133-155. http://dx.doi.org/10.1023/A:1011381114782

Mustari, M. I., Yaakob, R., Chik, S. @ N., \& Kilani, K. A. J. dan A. (2006). Permasalahan Ibu Tunggal Dalam Melaksanakan Tanggungjawab Pendidikan Anak-anak: Satu Kajian di Kawasan Sura, Dungun, Terengganu Darul Iman. Krisis dan Konflik Institusi Keluarga. Utusan Publications \& Distributor Sdn Bhd. Kuala Lumpur.

Myers, J. E., \& Sweeney, T. J. (2004). The Indivisible Self: An Evidence-Based Model of Wellness. Journal of Individual Psychology, 60(3), 234-245.

Othman, W. H. (1995). Fenomena Ibu Tunggal Dalam Masyarakat. Ciri-ciri dan Cara Menghadapinya. Kelana Jaya (Kertas Kerja Dalam Seminar Ibu Tunggal Kebangasaan, 7-9 Julai 1995).

Peden, A. R., Rayens, M. K., Hall, L. A., \& Grant, E. (2004). Negative thinking andthe mental health of low-income single mothers. Journal of Nursing Scholarship, 36, 337-344. http://dx.doi.org/10.1111/j.15475069.2004.04061.x

Rice, F. P. (2001). Human Development: A Life-Span Approach. Upper Saddle River: New Jersey.

Richards, L. N. (1989). The precarious survival and hard-won satisfactions of white single-parent families. Family Relations, 38(4), 396-403. http://dx.doi.org/10.2307/585744

Richards, L. N., \& Schmiege, C. J. (1993). Problems and strengths of single-parent families: Implications for practice and policy. Family Relations, 42(3), 277-285. http://dx.doi.org/10.2307/585557

Rowntree, D. (1981). Developing Courses for Students. London: McGraw-Hill.

Smith, M. J. (1980). The social consequences of single parenthood: a longitudinal perspective. Family Relations, 29(1), 75-81. http://dx.doi.org/10.2307/583719

Spielberger, C. D. (1999). STAXI-2: State Trait Anger Expression Iinventory-2. Lutz, FL: Professional Resources Assessments.

Starko, T. J. (1991). Parent stress and parent trrational beliefs: Mother father differences (Unpublished master's thesis). University of Alberta, Canada.

Syarifah, C. (2003). Permasalahan ibu tunggal dalam melaksanakan tanggugjawab pendidikan anak-anak. Satu 
kajian di kawasan Sura, Dungun Terengganu Darul Iman. Universiti Teknologi Malaysia.

Usó-Doménech, J. L., \& Nescolarde-Selva, J. (2013). Topological structures of complex belief systems (II): Textual materialization. Complexity, 19(2), 50-62. http://dx.doi.org/10.1002/cplx.21476

Walen, S. R., DiGiuseppe, R., \& Dryden, W. (1992). A practitioner's guide to a Rational-Emotive Therapy (2nd ed.). New York: Oxford University Press.

Wijnberg, M. H., \& Reding, K. M. (1999). Reclaiming a stress focus: the hassles of rural, poor single mothers. Families in Society, 80(5), 506-515. http://dx.doi.org/10.1606/1044-3894.1480

Wilcox, S., Evenson, K. R., \& Aragaki, A. (2003). The effects of widowhood on physical and mental health, health behaviors, and health Outcomes: the women's health initiative. Health Psychology, 22, 513-522. http://dx.doi.org/10.1037/0278-6133.22.5.513

Wilcox, W. B. (2002). Then comes marriage? Religion, race, and marriage in urban America (Center for Research on ChildWellbeingWorking Paper No. 02-13-FF). Philadelphia: University of Pennsylvania, Center for Research on Religion and Urban Civil Society.

Yahaya, A. Y. B., Ramli, J., Yahaya, N., \& Abd. Rahman, R. R. R. R. (2009). The Relationship between Dimensions of Personality, Self Concept and Family Influence on Students in the FELDA Scheme in Johore Malaysia. European Journal of Social Science, 11(2).

\section{Copyrights}

Copyright for this article is retained by the author (s), with first publication rights granted to the journal.

This is an open-access article distributed under the terms and conditions of the Creative Commons Attribution license (http://creativecommons.org/licenses/by/3.0/). 